\title{
Evaluation of Biogas Production Yields of Different Waste Materials
}

\author{
Bahtiyar Ozturk $^{1}$ \\ ${ }^{1}$ Environmental Eng. Dept., Eng. Faculty, Ondokuz Mayis Univ., Samsun, Turkey \\ Correspondence: Bahtiyar Ozturk, Environmental Eng. Dept., Eng. Faculty, Ondokuz Mayis Univ., Samsun \\ 55200, Turkey. E-mail: bozturk@omu.edu.tr
}

Received: October 18, 2012 Accepted: November 12, 2012 Online Published: November 28, 2012

doi:10.5539/esr.v2n1p165

URL: http://dx.doi.org/10.5539/esr.v2n1p165

\begin{abstract}
Biogas production from three different sources namely, cattle manure, cheese whey and blood, which have different characteristics, were investigated comparatively. Biogas production rates of $0.63,0,72$ and $0,641 \mathrm{~min}^{-1}$ $\mathrm{m}^{-3}$ were obtained from the digestion of manure, co-digestion of manure-cheese whey and manure-blood, respectively, at $35 \pm 2{ }^{\circ} \mathrm{C}$. Phosphorus $\left(\mathrm{PO}_{4}^{3-}\right)$ and volatile solid materials (VSM) are important for anaerobic bacteria as much as C:N ratio. A 54\% of reduction in VSM and a $52 \%$ reduction in $P_{4}^{3-}$ were observed in 30 days of digestion of manure. The amount of total nitrogen (Tot-N) decreased $10 \%$ in 30 days of digestion but ammonium-nitrogen $(\mathrm{Am}-\mathrm{N})$ increased $46 \%$ at the same duration of time. Manure, during co-digestion, buffered and inoculated the cheese whey and blood, and converted them to the energy source. An average COD removal of $52 \%$ or $34 \%$ is also possible during co-digestion of cheese whey or blood with manure.
\end{abstract}

Keywords: biogas production, manure, cheese whey, blood

\section{Introduction}

Solid and liquid wastes including soluble and biodegradable organic materials create serious environmental problems when disposed to the environment in an uncontrolled manner but they can be valued as an energy source if decomposed in a controlled anaerobic chamber. Wastewaters from slaughterhouses and cheese factories fall into this category and it is difficult to treat these liquid effluents in a conventional wastewater treatment process due to their high organic loadings and requirements to long hydraulic retention times and large reactor volumes (Borja et al., 1998).

Slaughterhouses produce animal by-products such as blood, bones and fat and they are transported to rendering plants for their safe processing, disposal and reuse in most countries. But, in many countries outside the European Union (EU), the management of animal by-products is not regulated and blood is disposed of directly into the environment. Slaughterhouse wastewater has a complex composition and is very harmful to the environment (Polpraset et al., 1992). Its polluting characteristic comes especially from blood if it is not properly collected and recovered back, and the strength of wastewater varies among slaughterhouses but variation is independent of plant capacity (Masse et al., 2000). Blood has a chemical oxygen demand (COD) of 375, 000 $\mathrm{mg} . \mathrm{l}^{-1}$ and it is one of the major dissolved pollutants in slaughterhouse wastewater (Tritt \& Schuchardt, 1992). It is difficult to treat this type of wastewaters in a conventional biological process which has lower hydraulic retention time, and their effluents do not offer the solution to satisfy environmental requirements. Anaerobic process is an alternative for the treatment of highly loaded effluents such as slaughterhouse wastewater which has high concentrations of COD and other biodegradable components (Spece, 1999). Ruiz et al. (1997) and Borja et al. (1998) treated slaughterhouse wastewater in an up-flow anaerobic sludge blanket (UASB) reactor and they obtained a COD removal more than $90 \%$ at a hydraulic retention time (HRT) of 0.5 days and a temperature of about $37{ }^{\circ} \mathrm{C}$. Because of differences between the statements of their results, it is difficult to compare biogas yields. Alvarez and Liden (Alvarez \& Liden, 2008) mixed fruit and vegetable wastes with slaughterhouse waste and co-digested in an anaerobic reactor at $35{ }^{\circ} \mathrm{C}$. They indicated that it is possible to reduce the volatile solid material (VSM) contents of about $50 \%$ and $65 \%$ and to obtain a methane yield of about $0.3 \mathrm{~m}^{3} \mathrm{~kg}^{-1} \mathrm{VSM}$.

Cheese manufacturing industry generates large amounts of high strength wastewaters characterized by high biological oxygen demand (BOD) and COD concentrations with values of 40,000-60,000 mg. $1^{-1}$ and 50,000-80,000 mg..$^{-1}$, respectively (Ben-Hassan \& Ghaly, 1994; Omil et al., 2003; Farizoglu et al., 2004; Demirel et al., 2005). Annual whey production in the world is estimated between 150 and 200 million tons and it 
increases about 2\% per year (Najafpour et al., 2008; Smithers, 2008), and approximately half of it disposed into rivers, lakes, or other water bodies. Because of the heavy organic loadings, cheese whey creates serious pollution problems when discharged into water bodies without applying any treatment procedure. It also causes a significant loss of resources which can be assessed as a protein source or for biogas production. Treatment of cheese whey effluent in a conventional wastewater treatment plant is difficult due to its high BOD values and it may disrupt the biological processes used for household wastewater (Cristiani-Urbani et al., 2000). Malaspina et al. (1996) indicated that it is difficult to treat cheese whey aerobically because of the lack of alkalinity, the high COD concentration and tendency to acidify very rapidly. Chemical treatment, as a full treatment method, is also not enough to meet discharge limits into the sewerage or to the receiving water bodies. It can be used as a pre-treatment stage before biological or advanced treatment.

Rusten et al. (1993) used lignosulphonic acid (LSA, $\mathrm{C}_{20} \mathrm{H}_{26} \mathrm{O}_{10} \mathrm{~S}_{2}$ ), ferric chloride/sulphate (JKL, $\mathrm{FeCl}_{3} / \mathrm{FeSO}_{4}$ ) and carboxy methyl cellulose $\left(\mathrm{CMC}, \mathrm{CH}_{2} \mathrm{CO}_{2} \mathrm{H}\right)$ as coagulant in order to remove $\mathrm{COD}$ from dairy wastewater. They obtained a COD removal of $60 \%$ with CMC solution of $12 \mathrm{mg} \mathrm{l}^{-1}$ at $\mathrm{pH}$ of 4.0 . In order to reuse dairy wastewater, Sarkar et al. (2006) applied three sequencing treatment methods namely coagulation, carbon adsorption and membrane separation and they achieved about $40 \%$ of COD removal. Tanik et al. (2002) used $\mathrm{FeCl}_{3}, \mathrm{FeSO}_{4}$ and alum to remove COD from dairy wastewater and they obtained a COD removal of $72 \%, 59 \%$ and $54 \%$, respectively, with the optimum $\mathrm{pH}$ values between 4.0 and 4.5 . Kushwaha et al. (2010) and Tchamango et al. (2010) applied an electrochemical technique using iron and aluminium electrodes to remove dissolved COD from synthetic dairy wastewater. Their results showed that it is possible to remove dissolved $\mathrm{COD}$ as much as $70 \%$ employing electrochemical technique. One may find more information about the treatment of dairy wastewater in review articles written by Demirel et al. (2005) and Kushwaha et al. (2011).

Wastewater which has high organic loading needs to be treated generally by anaerobic digestion at longer hydraulic retention times (Borja et al., 1998; Demirel et al., 2005; Tritt 1992; Rajeshwari et al., 2000). The efficiency of anaerobic digestion process is dependent on the type and composition of the material to be digested. Anaerobic digestion can also be used to recover bio-energy in the form of biogas, which consists mainly of methane $\left(\mathrm{CH}_{4}\right)$ and carbondioxide $\left(\mathrm{CO}_{2}\right)$. The microbial populations involved in anaerobic digestion require sufficient nutrients to grow and multiply. Major nutrients for the growth of species and optimum nutrient removal are carbon $(\mathrm{C})$ and nitrogen $(\mathrm{N})$. The optimum $\mathrm{C} / \mathrm{N}$ ratio for producing methane is around 20-35 (Tarbaghia, 1993; Hills, 2003; Ghasimi et al., 2009). If the $\mathrm{C} / \mathrm{N}$ ratio is too high, the process is limited by $\mathrm{N}$ availability and the resulted acidification retards methanogenesis activity, and if it is too low, ammonia may be found in quantities large enough to be toxic to the bacterial population. In addition to carbon and nitrogen in the digestion system, microorganisms also need micronutrients (trace minerals) and phosphorus for their growth. Also, some operating parameters such as temperature, $\mathrm{pH}$, HRT and organic loading rate (OLR) need to be controlled for the digestion of organic materials and for optimum biogas production.

The organic materials differ with regard to their chemical composition. Sometimes that composition cannot be suitable for the optimum bacteria growth and the biogas production. For example, lactose which is the main component of whey solids promotes the growth of acid forming bacteria under anaerobic conditions. These bacteria break down lactose into short chain fatty acids such as acetic, propionic, butyric and other acids and cause a rapid decrease of medium $\mathrm{pH}$. This low $\mathrm{pH}$ has negative effect on methane-producing bacteria and causes low biogas yields (Hanson, 1982; Gally, 1996; Gelegenis et al., 2007). This problem has been overcome by co-digestion of different organic materials, because co-digestion can provide a better nutrient balance and therefore better digester performance and higher biogas yield (Mata-Alvarez, 2000). In order to increase digestion performance and methane yield, co-digestion of solid slaughterhouse waste, manure, fruit and vegetable waste (Alvarez \& Liden, 2008), manure with straws (Hashimoto, 1983; Fisher \& Iannotti, 1983), cattle slurry with fruit and vegetable wastes and chicken manure (Callaghan et al., 2002), manure with potato tuber (Kaparahu \& Rintala, 2005), manure with sugar beets (Umetsu et al., 2006), manure with corn silage (Amon et al., 2007), manure with energy crops and crop residues (Lehtomaki et al., 2007), manure with olive mill wastewater and cheese whey (Dareioti et al., 2009), manure with cheese whey (Gally, 1996; Gelegenis et al., 2007; Lo \& Liao, 1989; Kavacik \& Topaloglu, 2010), cheese whey, corn silage, beet pulp, carrot, residues and glycerine (Kacprzak et al., 2010) and cheese whey, poultry waste and cattle dung had been investigated previously.

In this study, biogas production from the anaerobic digestion of manure, co-digestion of manure and cheese whey and manure and blood were investigated. Removal efficiencies of total solid materials (TS), volatile solid materials (VSM), COD, ammonia-nitrogen $(\mathrm{Am}-\mathrm{N})$ and phosphorus $\left(\mathrm{PO}_{4}^{3-}\right)$ were also investigated during anaerobic digestion. 


\section{Material and Methods}

Biogas production was performed in a cylindrical anaerobic reactor (digester) made from stainless steel (type 316) with a total volume of $4 \mathrm{~m}^{3}$ (working volume is $3.6 \mathrm{~m}^{3}$ ). Liquid inside the reactor was agitated by an impeller connected to a geared motor which was installed on the top of reactor. A constant mixing rate of $20 \mathrm{rpm}$ was applied throughout the studies. Digester temperature was kept constant at $35 \pm 2{ }^{\circ} \mathrm{C}$ using four thermostatic resistances connected to electricity of $220 \mathrm{~V}$. In order to protect the digester against the heat alteration of the surrounding, the digester was isolated using glass wool of $10 \mathrm{~cm}$ thick. Liquid mixture was prepared in a cylindrical concrete chamber of 1001 before feeding the digester, and then the mixed liquid was fed in the digester using a stopper controlled manually. Biogas produced was stored in a tank of 1201 using a compressor connected to a pressure indicator. Production rate of biogas was measured by a gas counter and cross-checked by a soap bubble meter.

Four different biogas production experiments were carried out: digestion of manure, digestion of whey, co-digestion of whey with manure and co-digestion of blood with manure. Experiment 1: Cattle manure was supplied from animal farm of Ondokuz Mayis University and mixed with tap water and fed to the digester. $30 \mathrm{~kg}$ of wet manure were mixed with $70 \mathrm{~kg}$ of water to form liquid manure. Total volume of digester $\left(3.6 \mathrm{~m}^{3}\right)$ was filled in one day. After first feeding, biogas production, $\mathrm{pH}$ of the digester liquid, concentrations of total solid materials (TS), volatile solid materials (VSM), ammonia-nitrogen (Am-N), total nitrogen (Tot-N) and phosphate $\left(\mathrm{PO}_{4}^{3-}\right)$ in the digester liquid were measured daily. Liquid samples were received from a sampling point on the digester body. Optimum HRT also determined by this experiment. Thirty days after first feeding of the digester, 2001 of liquid manure which gives 18 days of HRT was fed into digester daily. Biogas yield of this semi-continuous feeding of the digester was also traced. Experiment 2: Whey which was supplied from a cheese manufacturing plant at Ondokuz Mayis University campus fed into empty digester. $\mathrm{pH}$, biogas yield and COD concentration of the whey in the digester were determined during this experiment. Experiment 3: Manure was mixed with whey (in order to obtain a $10 \%$ of TS in the liquor, weigh ratio of manure to whey was adjusted to $35 / 65$ ) and fed into the digester. Biogas yield, $\mathrm{pH}$, concentrations of SM, VSM, Am-N, Tot-N and $\mathrm{PO}_{4}^{3-}$ were measured throughout 18 days without making new feeding into the digester. After 18 days, digester was fed semi-continuously every day with whey-manure mixture. Experiment 4: Blood was supplied from a slaughterhouse and mixed with manure and water (weigh ratio of blood/manure/water is 30/20/50) and fed into the digester. Following 18 days of first feeding the digester was fed semi-continuously every day by taking into account the HRT of 18 days. Biogas yield, $\mathrm{pH}$ and COD concentration of this mixture in the digester were measured daily.

pH was measured by an electrode (Sartorius Docu pH meter), while total COD, total and volatile solid materials (TS, VSM), ammonium nitrogen (Am-N), total Kijeldahl nitrogen Tot-N) and phosphorus as ortho-phosphate were determined by the standard recommended procedure (APHA, AWWA, WEF, 1995). Methane content of the biogas was measurement by a GC/MS (Shimadzu QP2010, Japan) using a capillary column (Carboxen, $30 \mathrm{~m}$, I.D. $0.32 \mathrm{~mm}$, max.tep. $375^{\circ} \mathrm{C}$ ) and helium as carrier gas.

\section{Results and Discussion}

Since the construction of first biogas plant in India in 1856, thousands of biogas plants have been built around the world in order to get renewable energy, to solve environmental pollution problems caused by organic wastes and to gain fertilizer. Many research articles have been published about biogas production and its benefits, and it keeps continuously its importance because of those reasons.

In this study four different biogas production experiments were carried out namely digestion of manure, digestion of whey, co-digestion of whey with manure and co-digestion of blood with manure. Figure 1 depicts the biogas production and its methane content with respect to start up duration of 33 days. Biogas production rate $\left(0.631 \mathrm{~min}^{-1} \mathrm{~m}^{-3}\right.$ reactor volume) and its methane content $(60 \%)$ reached the maximum in 18 and 20 days, respectively, at $35 \pm 2{ }^{\circ} \mathrm{C}$ and $1 \mathrm{~atm}$. Thus, digestion time of 18 days was determined as hydraulic retention time (HRT). Methane content was lower in first 5 days because of the dilution of biogas with air on digestion liquor inside the reactor. That air was pushed out of the reactor in time by biogas produced and the methane content reached to $60 \%$. Biogas production declined after 20 days of start up. Methane content of the biogas was also begun to decrease by increasing digestion time, but not like the biogas. Methane molecule is a combination of hydrogen and carbon, but hydrogen is produced during and just after acidification of the organic materials. Therefore, hydrogen production and related methane content of the biogas start to decrease in prolonged time without addition of new organic materials. 


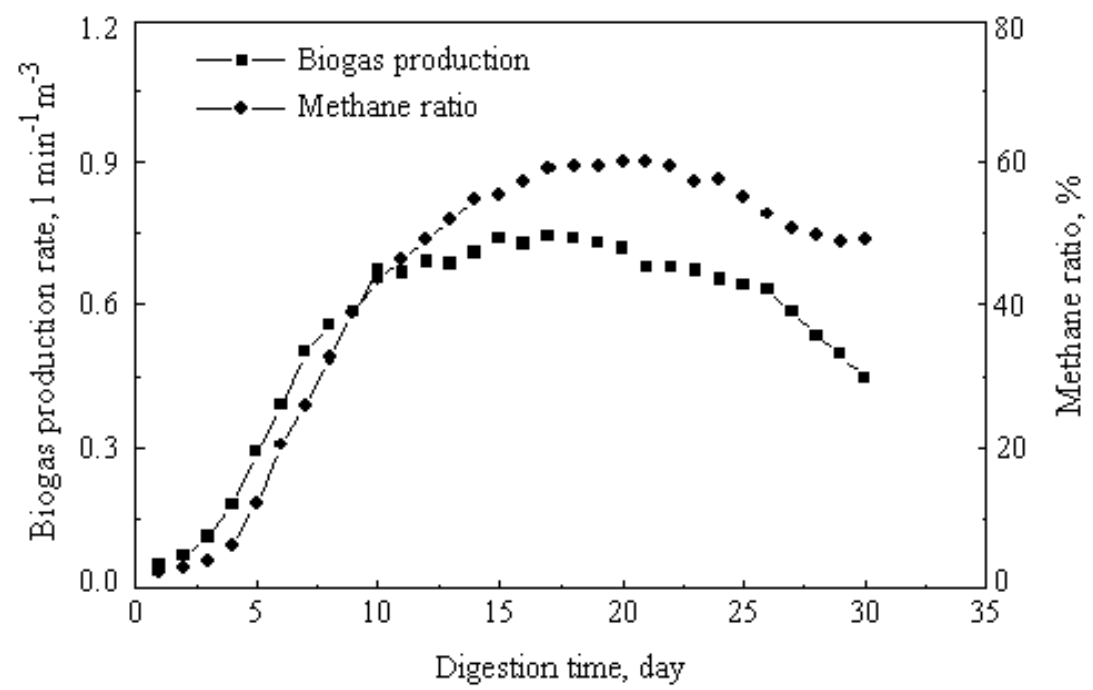

Figure 1. Biogas production from cattle manure and its methane content

$\mathrm{pH}$ of the digestion liquor increased from 7.4 to 6.8 in 18 days. This $\mathrm{pH}$ rage is optimum for the growth of bacterial culture and it can be said that there is no negative effect of $\mathrm{pH}$ on the biogas production from cattle manure. Most of the research results indicate that the ratio of carbon to nitrogen $(\mathrm{C}: \mathrm{N})$, micronutrients (trace elements) and phosphorus are important for anaerobic growth of bacteria during biogas production, and the optimum range for C:N ratio is 20-35 (Hills, 1979; Tarbaghia, 1993; Ghasimi et al., 2009). Our results show that $\mathrm{PO}_{4}^{3-}$ uptake by bacteria and reduction in VSM concentration happen through anaerobic digestion of manure (Figures. 2 and 3). C:N ratios of liquor manure, blood-manure and manure-whey mixtures were $16.8 \pm 2,14 \pm 1$ and $31 \pm 2$ for manure, respectively. Experimental results showed that these $\mathrm{C}: \mathrm{N}$ ratios did not changed during digestion. A $54 \%$ of reduction in VSM and a $52 \%$ reduction in $\mathrm{PO}_{4}^{3-}$ were observed in 30 days of digestion while just 9.9\% reduction in total solid material (TS) content was occurred (Figs.2 and 3). It can be said that there is a relation between biogas production rate and the amount of VSM and $\mathrm{PO}_{4}^{3-}$ concentration in the digestion liquor. Gelegenis et al. (2007) indicated that biogas production was increased by the increasing VSM content in the digestion chamber. As it can be seen from the Figure 3, the amount of Tot-N decreased $10 \%$ in 30 days of digestion but Am-N increased $46 \%$ at the same duration of time. The increase in ammonia could have caused the decrease in biogas production after 18 days of digestion time. Hashimoto (1986) and Borja et al. (1996) mentioned that the higher amount of ammonia inhibits the growth of bacteria, and Strik et al. (2006) indicated that the tolerable free ammonia concentrations varied from $55 \pm 11$ to $150 \mathrm{mg} \mathrm{NH}_{3} \mathrm{l}^{-1}$. Some other parameters such as temperature, HRT and OLR must also be optimized for the higher biogas yield. Sarapatka (1994) indicated that the main factors influencing anaerobic treatment of farmyard manure are the temperature and quality of the farmyard manure, and dietary regime of the livestock.

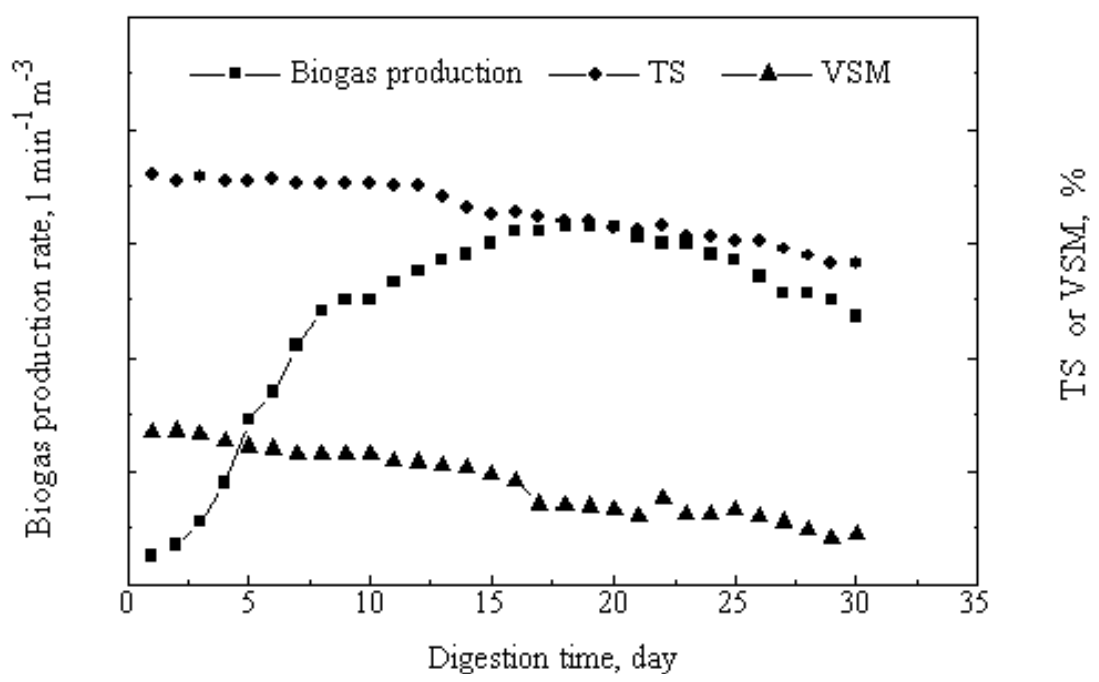

Figure 2. Effect of anaerobic digestion on solid and volatile solid materials of manure 


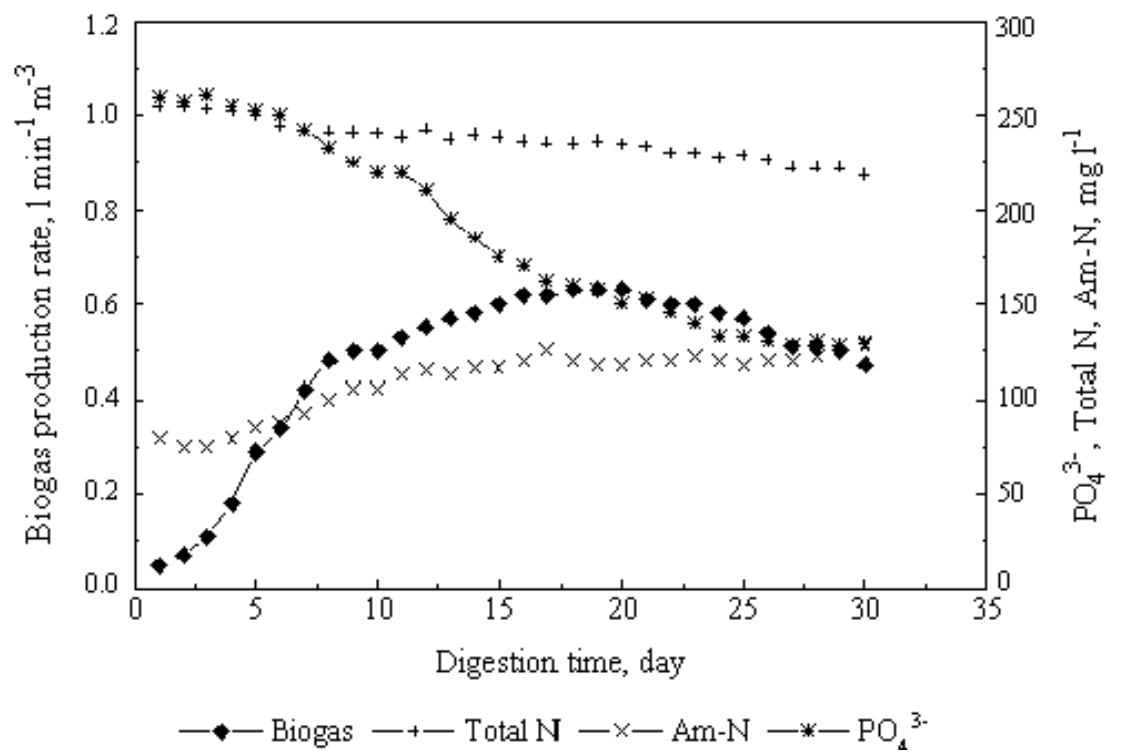

Figure 3. Variation of concentrations of $\mathrm{PO}_{4}^{3-}$, Total $\mathrm{N}$ and $\mathrm{NH}_{3}-\mathrm{N}$ through anaerobic digestion of manure

Cheese whey has very high BOD and COD concentrations, 40,000-60,000 $\mathrm{mg}^{-1}$ and 50,000-80,000 $\mathrm{mg}^{-1}$, respectively (Ben-Hassan \& Ghaly, 1994; Gelegenis et al., 2007) which need to be treated to provide discharge limits. COD concentrations of manure-whey mixtures fed into the digestion chamber were between $35,000-36,000 \mathrm{mg} \cdot \mathrm{l}^{-1}$ with the average value of $35,426 \mathrm{mg} \mathrm{l}^{-1}$. Anaerobic treatment is the most suitable process for the treatment of high strength organic effluents such as cheese whey, and it also leads to biogas production (Gelegenis et al., 2007). Biogas production rate and its methane content are shown in Figure 4 together with pH for the digestion of cheese whey. Gas production started two days after first feeding of the digestion system and reached to maximum in $8^{\text {th }}$ day, and the highest methane content of the gas was measured as $20 \%$ in $10^{\text {th }}$ day. Compared to the biogas produced from the digestion of cattle manure and its methane content, the amount of biogas produced using cheese whey in per cubic meter of the digestion volume in per minute and its methane content were 143 and 2 times less, respectively. As it can be seen from the Figure 4, pH of the digestion liquor dropped to acidic levels in fifteen days because of the rapid acidification and little buffering capacity of the cheese whey. The main components of cheese whey are lactose $\left(44-52 \mathrm{~g} \mathrm{l}^{-1}\right)$, protein $\left(6.1-6.6 \mathrm{~g} \mathrm{l}^{-1}\right)$, fat $(0.2-0.3 \mathrm{~g}$ $\mathrm{l}^{-1}$ ) and minerals (5-7.9 $\mathrm{g} \mathrm{l}^{-1}$ ) (Fox et al., 2000). Lactose in cheese whey is a readily degradable carbonhydrates and is broken down rapidly into short chain fatty acids such as acetic, propionic, butyric and other acids under anaerobic conditions (Kissalita et al., 1989; Kissalita et al., 1990). This acidification inhibits activity of methanogenic bacteria resulting in lower biogas yield.

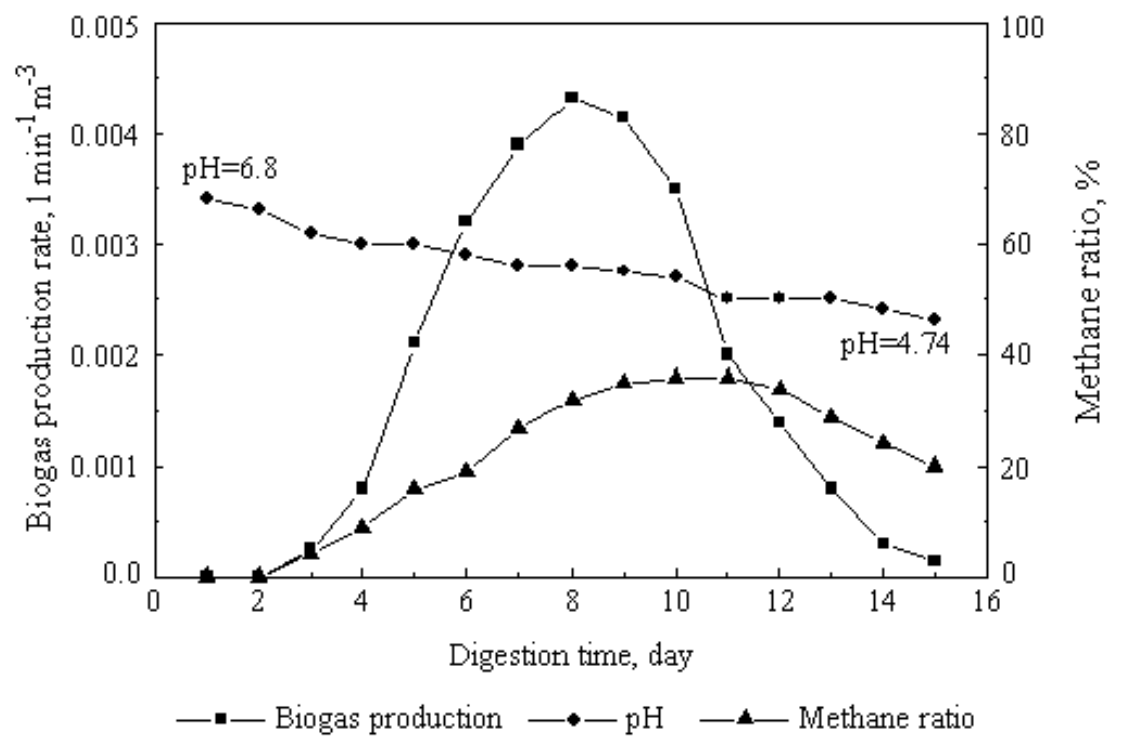

Figure 4. Variation of biogas production rate, methane content and $\mathrm{pH}$ during digestion of cheese whey 
Although whey has very high organic load and strong polluting potential when discharged directly into water bodies, it is complicated substrate for biogas production due to the process instability. One option to cope with the problems confronted during anaerobic digestion of whey and to improve its biogas yields is to co-digest of whey with cattle manure. In this study, in order to eliminate the acidification of whey during anaerobic digestion, the digester was filled with the manure-whey mixture $(35 / 65, \mathrm{w} / \mathrm{w})$ and the biogas yield and its methane content were measured. After 18 days from the first feeding, the digester was fed with the manure-whey mixture daily maintaining the HRT as 18 days. Figure 5. represents the biogas yield and its methane content obtained from the co-digestion of whey with manure. As it can be seen from the figure, manure stabilized the process, and there is no decrease in biogas production and its methane content compared to the values obtained from the digestion of whey alone. Even biogas yield and its methane content obtained from the co-digestion of whey with manure is higher than those obtained from digestion of manure alone. Biogas production rate and its methane content of the whey-manure mixture were determined as $0.721 \mathrm{~min}^{-1} \mathrm{~m}^{-3}$ and $63 \%$ at $35 \pm 2{ }^{\circ} \mathrm{C}$, respectively. Because of the ammonia produced from the digestion of manure neutralizes the acid produced from the digestion of whey, and manure provides the missed nutrients for whey; hence, co-digestion of whey with manure increased the biogas yield.

A maximum COD reduction of $52 \%$ occurred during co-digestion of whey with manure (Table 1 ). It can be said that the co-digestion of whey with manure is not a suitable process for the removal of pollutants. Results mentioned in the literature show much higher COD removal rate, but those results were obtained from different anaerobic processes. For example, Malaspina et al. (1996) achieved a COD removal up to 98\% in a down-flow and up-flow hybrid reactor connected serially, Lo and Liao (1989) achieved more than 75\% COD removal in a lab-scale rotating anaerobic contact reactor, Yan et al. (1990) achieved a COD removal of 98\% in a lab-scale upward-flow anaerobic sludge blanket (UASB) reactor, Patel et al. (1995) achieved a COD removal of 81\% in an up-flow fixed film anaerobic reactor. Co-digestion of whey with manure has also some other advantages such as protection of environment against pollution, improving the fertilizer value of the manure and recycling of nutrients back into the agricultural sector.

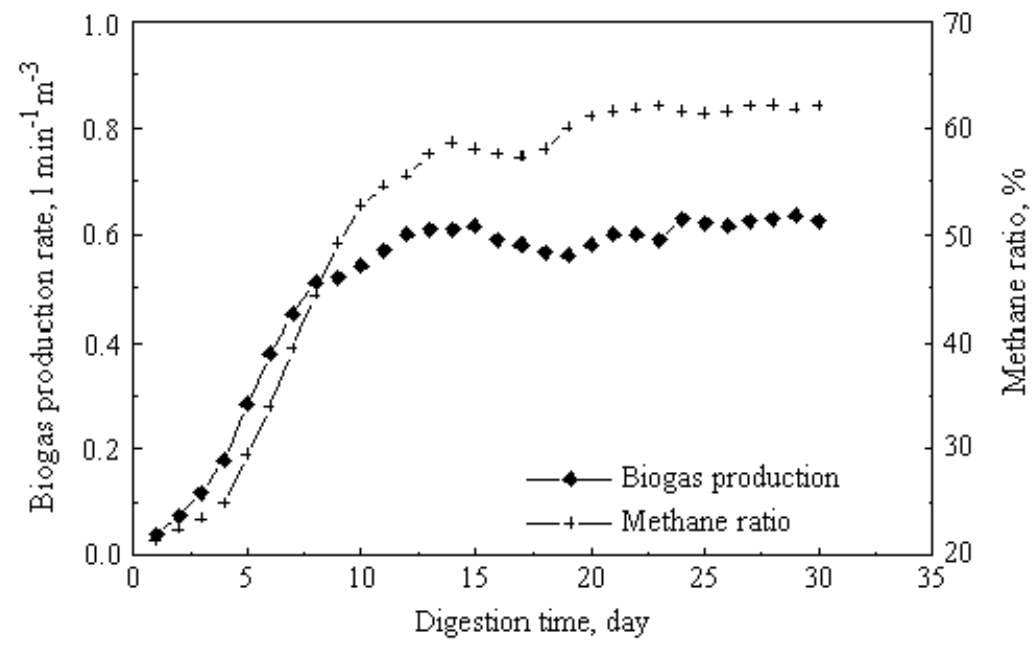

Figure 5. Variation of biogas production rate and its methane content during co-digestion of cheese whey with manure

Table 1. Variation of some physical and chemical parameters during anaerobic co-digestion of whey with manure

\begin{tabular}{llll}
\hline Parameter & Influent conc./ $\mathrm{mg} \mathrm{l}^{-1}$ & Efluent conc./ $\mathrm{mg} \mathrm{l}^{-1}$ & Removal efficiency/\% \\
\hline Total solid material, TS & 98977 & 83140 & 16 \\
Volatile solid material, VSM & 64285 & 35357 & 45 \\
COD & 35426 & 17004 & 52 \\
Am-N & 185 & 191 & -3 \\
Total N & 230.8 & 166.1 & 28 \\
Phosphate & 215.4 & 144.5 & 33 \\
\hline
\end{tabular}


Effluents from slaughterhouses have very high pollution loads which come mainly from blood if the blood is mixed with other waste by-products. In order to reduce the waste load, an efficient blood recovery process must be applied. In this study, despite the recovery of blood, the blood was rotted anaerobically without mixing with any other material and with manure at $35 \pm 2{ }^{\circ} \mathrm{C}$. There was no gas produced during digestion of blood alone, except a bad smell. But, 0,64 $1 \mathrm{~min}^{-1} \mathrm{~m}^{-3}$ biogas was produced from manure-water-blood mixture (20/30/50, w/w) (Figure 6) with a methane ratio of $59 \%$ and there was no bad smell of this process. A $50.4 \%$ of COD (total COD) removal was achieved in 12 days after first feeding of the digestion system; but a $34.2 \%$ of COD removal was achieved during semi-continuously feeding (Figure 6). Fresh liquid may reach the discharge point of the digestion system and can cause that increase of the COD concentration.

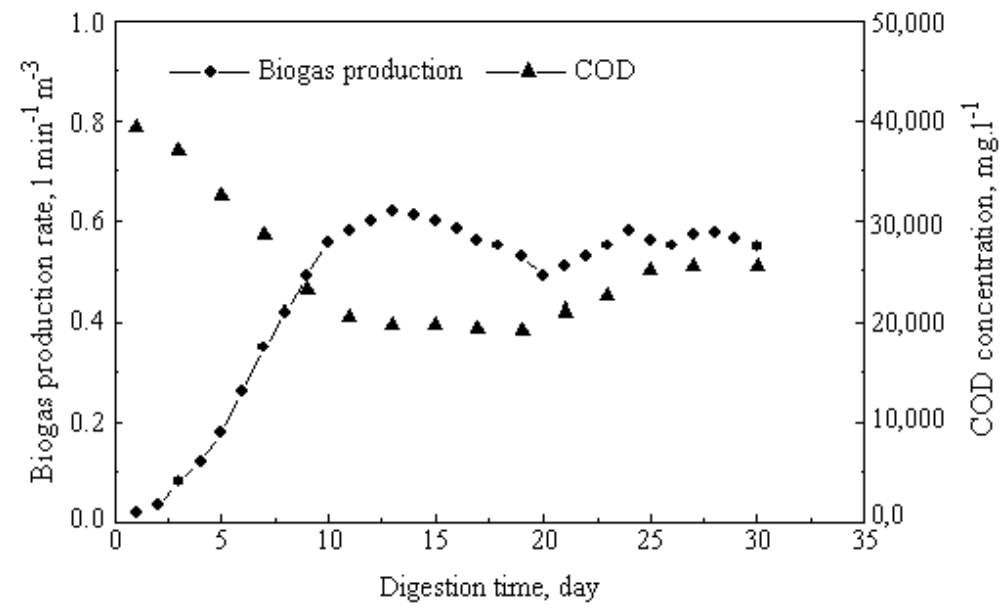

Figure 6. Variation of biogas production rate, its methane content and COD concentration during co-digestion of blood with manure

Digestion of blood with manure improves the discharge water quality of the wastewater treatment process of a slaughterhouse, saves the energy used for aerobic treatment, recovers the biogas, restricts the odour produced during aerobic treatment and recycles the nutrients back into the agricultural sector.

\section{Conclusions}

Biogas production from three different sources namely, cattle manure, cheese whey and blood, which have different characteristics, were investigated comparatively. The results obtained can be concluded as:

Biogas production rate $\left(0.631 \mathrm{~min}^{-1} \mathrm{~m}^{-3}\right)$ and its methane content $(60 \%)$ reached the maximum in 18 and 20 days, respectively, at $35 \pm 2{ }^{\circ} \mathrm{C}$ when cattle manure was digested anaerobically. There was no negative effect of pH on the biogas production from cattle manure; it was changed from 7.4 to 6.8. Results indicated that some materials, in addition to $\mathrm{C}: \mathrm{N}$ ratio mentioned in many papers, are vital for the growth of anaerobic bacteria; these are volatile solid material (VSM) and phosphorus $\left(\mathrm{PO}_{4}^{3-}\right)$. Ammonia concentration in digestion liquor was increased, but its negative effect was not so obvious.

It is difficult to produce biogas from cheese whey alone, because cheese whey acidifies during anaerobic digestion. In order to stabilize the digestion process of cheese whey, it was mixed with manure. Considering the manure, mixing cheese whey with manure eliminates the rapid acidification of whey and increases the biogas yield and its methane content as $14 \%$ and 5\%, respectively. COD which comes mainly from the whey can be removed, as much as $50 \%$, during anaerobic digestion of whey with manure. It is also possible to produce biogas from blood, which has very high polluting potential and reduces the efficiency of conventional aerobic wastewater treatment process of the slaughterhouse. But, biogas production from blood alone is so difficult, it must be mixed with another organic waste. The best and straightforward organic waste in a slaughterhouse is manure which comes from stomach of dead animals and includes higher amount of anaerobic bacteria. In this study, 0,64 $1 \mathrm{~min}^{-1} \mathrm{~m}^{-3}$ biogas with a methane ratio of $59 \%$ was obtained from manure-water-blood mixture (20/30/50, w/w). An average COD removal of 34\% is also possible during co-digestion of blood with manure.

Consequently, co-digestion of manure with cheese whey or blood helps to convert these waste organic materials to the energy source, protects the environment and recycles the organic materials back to the agricultural sector. 


\section{Acknowledgements}

The authors gratefully acknowledge Turkish Scientific and Technological Research Institution (TUBITAK) for the financial support through the project numbered as $105 \mathrm{Y} 084$.

\section{References}

Alvarez, R., \& Liden, G. (2008). Semi-continuous co-digestion of solid slaughterhouse waste, manure, and fruit and vegetable waste. Renew. Energy, 33, 726-734. http://dx.doi.org/10.1016/j.renene.2007.05.001

Amon, T., Amon, B., Kryvoruchko, V., Zollitsch, W., Mayer, K., \& Gruber, L. (2007). Biogas production from maize and dairy cattle manure-Influence of biomass composition on the methane yield. Agricult. Ecosyst \& Environ, 118, 173-182. http://dx.doi.org/10.1016/j.agee.2006.05.007

APHA, AWWA, \& WEF. (1995). Standard methods for the examination of water and waste water (19th ed.). Washington DC, USA: American Public Health Association.

Ben-Hassan, R. M., \& Ghaly, A. E. (1994). Continuous propagation of Kluyveromyces fragilis in cheese whey for pollution potential reduction. Appl. Biochem. Biotechnol., 47, 89-105.

Borja, B., Banks, C. J., Wang, B. Z., \& Mancha, A. (1998). Anaerobic digestion of slaughterhouse wastewater using a combination sludge blanket and filter arrangement in a single reactor. Biores. Tech., 66, 125-133. http://dx.doi.org/10.1016/S0960-8524(98)00004-2

Borja, R., Sanchez, E., \& Weiland, P. (1996). Influence of ammonia concentration on thermophilic anaerobic digestion of cattle manure in upflow anaerobic sludge blanket (UASB) reactors. Proc. Biochem., 31, 477-483. http://dx.doi.org/10.1016/0032-9592(95)00099-2

Callaghan, F. J., Waste, D. A. J., Thayanity, K., \& Forster, C. F. (2002). Continuous co-digestion of cattle slurry with fruit and vegetable wastes and chicken manure. Biomass and Bioen., 22, 71-77. http://dx.doi.org/10.1016/S0961-9534(01)00057-5

Cristiani-Urbani, E., Netzahuatl-Munoz, A. R., Manriquez-Rojas, F. J., Juarez-Ramirez, C., Ruiz-Ordaz, N., \& Galindez-Mayer, J. (2000). Batch and fed-batch cultures for the treatment of whey with mixed yeast cultures. Proc. Biochem., 35, 649-657. http://dx.doi.org/10.1016/S0032-9592(99)00116-8

Dareioti, M. A., Dokianakis, S. N., Stamatelatou, K., Zafiri, C., \& Kornaros, M. (2009). Biogas production from anaerobic co-digestion of agroindustrial wastewater under mesophilic conditions in a two-stage process. Desalination, 248, 891-906. http://dx.doi.org/10.1016/j.desal.2008.10.010

Demirel, B., Yenigun, O., \& Onay, T. T. (2005). Anaerobic treatment of dairy wastewaters: a review. Proc. Biochem., 40, 2583-2595. http://dx.doi.org/10.1016/j.procbio.2004.12.015

Farizoglu, B., Keskiner, B., Yildiz, E., \& Nuhoglu, A. (2004). Cheese whey treatment performance of an aerobic jet loop membrane bioreactor. Proc. Biochem., 39, 2283-2291. http://dx.doi.org/10.1016/j.procbio.2003.11.028

Fisher, J. R., Iannotti, E. L., \& Fulhage, C. D. (1983). Production of methane gas from combinations of wheat straw and swine manure. Trans. Am. Soc. Agricult. Eng., 26, 546-548.

Fox, P. F., Guinee, T. P., Cogan, T. M., \& McSweeney, P. L. H. (2000). Fundamentals of Cheese Science (p. 608). Gaithersburg, Maryland: Apsen Publishers, Inc.

Gally, A. E. (1996). A comparative study of anaerobic digestion of acid cheese whey and dairy manure in a two-stage reactor. Biores. Tech., 58, 61-72. http://dx.doi.org/10.1016/S0960-8524(96)00105-8

Gelegenis, J., Georgakakis, D., Angelidaki, I., \& Mavris, V. (2007). Optimization of biogas production by co-digestion whey with diluted poultry manure. Renew. Energy, 32, 2147-2160. http://dx.doi.org/10.1016/j.renene.2006.11.015

Ghasimi, S. M. D., Idris, A., Chuah, T. G., \& Tey, B. T. (2009). The Effect of C:N:P ratio, volatile fatty acids and $\mathrm{Na}+$ levels on the performance of an anaerobic treatment of fresh leachate from municipal solid waste transfer station. African J. Biotech., 8, 4572-4581.

Hanson, G. (1982). End product inhibition in methane fermentation. Process. Biochem., 17, 45-49.

Hashimoto, A. G. (1983). Conversion of straw-manure mixtures to methane at mesophilic and thermophilic temperatures. Biotech. Bioeng., 25, 185-200.

Hashimoto, A. G. (1986). Ammonia inhibition of methanogenesis from cattle wastes. Agricult. Wastes, 17, 
241-261.

Hills, D. J. (1979). Effects of carbon: Nitrogen ratio on anaerobic digestion of dairy manure. Agricult. Wastes, 1, 267-278. http://dx.doi.org/10.1016/0141-4607(79)90011-8

Kacprzak, A., Krzystek, L., \& Ledakowicz, S. (2010). Co-digestion of agricultural and industrial wates. Chem. Pap., 64, 127-131. http://dx.doi.org/10.2478/s11696-009-0108-5

Kaparaju, P., \& Rintala, J. (2005). Anaerobic co-digestion of potato tuber and its industrial by-products with pig manure. Res. Conserv. Recy., 43, 175-188. http://dx.doi.org/10.1016/ j.resconrec.2004.06.001

Kavacik, B., \& Topaloglu, B. (2010). Biogas production from co-digestion of a mixture of cheese whey and dairy manure. Biomass and Bioen., 34, 1321-1329. http://dx.doi.org/10.1016/ j.biombioe.2010.04.006

Kissalita, W. S., Lo, K. V., \& Pinder, K. L. (1989). Kinetics of whey-lactose acidogenesis. Biotechnol. Bioeng., $33,623-630$.

Kissalita, W. S., Lo, K. V., \& Pinder, K. L. (1990). Influence of whey protein on continuous acidogenic degradation of lactose. Biotechnol. Bioeng., 36, 642-646.

Kushwaha, J. P., Srivastava, V. C., \& Mall, I. D. (2010). Organics removal from dairy wastewater by electrochemical treatment and residue disposal. Sep. and Purif. Technol., 76, 198-205. http://dx.doi.org/10.1016/j.seppur.2010.10.008

Kushwaha, J. P., Srivastava, V. C., \& Mall, I. D. (2011). An overview of various Technologies for the treatment of dairy wastewater. Crit. Rev. in Food Sci. and Nut., 51, 442-452. http://dx.doi.org/10.1080/10408391003663879

Lehtomaki, A., Huttunen, S., \& Rintala, J. A. (2007). Laboratory investigations on co-digestion of energy crops and crop residues with cow manure for methane production: Effect of crop to manure ratio. Res., Conserv. And Recyc., 51, 591-609. http://dx.doi.org/10.1016/ j.resconrec.2006.11.004.

Lo, K., \& Liao, P. (1989). Anaerobic-aerobic biological treatment of a mixture of cheese whey and dairy manure. Biol. Wastes, 28, 91-101. http://dx.doi.org/10.1016/0269-7483(89)90073-6

Malaspina, F., Cellamare, C. M., Stante, L., \& Tilche, A. (1996). Anaerobic treatment of cheese whey with a downflow-upflow hybrid reactor. Biores. Technol., 55, 131-139. http://dx.doi.org/10.1016/0960-8524(95)00187-5

Masse, D. I., \& Masse, L. (2000). Treatment of slaughterhouse wastewater in anaerobic sequencing batch reactors. Canadian Agricul. J., 42, 131-137.

Mata-Alvarez, J., Mace, S., \& Llabres, P. (2000). Anaerobic digestion of organic solid wastes: An overview of research achievements and perspectives. Biores. Technol., 74, 3-16. http://dx.doi.org/10.1016/S0960-8524(00)00023-7

Najafpour, G. D., Hashemiyeh, B. A., Asadi, M., \& Ghasemi, M. B. (2008). Biological treatment of dairy wastewater in an upflow anaerobic sludge-fixed film bioreactor. Am-Eura. J. Agric. \& Environ. Sci., 4, 251-257.

Omil, F., Garrido, J. M., Arrojo, B., \& Mendez, R. (2003). Anaerobic fitler reactor performance for the treatment of complex dairy wastewater at industrial scale. Water Res., 37, 4099-4108. http://dx.doi.org/10.1016/S0043-1354(03)00346-4.

Patel, P., Desai, M., \& Madamwar, D. (1995). Biomethanation of cheese whey using anaerobic upflow fixed film reactor. J. Ferment Bioeng., 79, 398-399. http:// dx.doi.org/10.1016/0922-338X(95)94006-D

Polprasert, C., Kemmadamrong, P., \& Tran, F. T. (1992). Anaerobic baffle reactor (ABR) process for treating a slaughterhouse wastewater. Environ. Tech., 13, 857-865. http://dx. doi.org/10.1080/09593339209385220

Rajeshwari, K. V., Balakrishnan, B., Kansal, A., Lata, K., \& Kishore, V. V. N. (2000). State-of-art of anaerobic digetion technology for industrial wastewater treatment. Renew. And Sustain. Energy Rev., 4, 135-156. http://dx.doi.org/10.1016/S1364-0321(99)00014-3

Ruiz, I., Veiga, M. C., de Santiago, P., \& Blazquez, R. (1997). Treatment of slaughterhouse wastewater in a UASB reactor and an anaerobic filter. Biores. Technol., 60, 251-258. http://dx.doi.org/10.1016/S0960-8524(97)00020-5

Rusten, B., Lundar, A., Eide, O., \& Odegaard, H. (1993). Chemical pretreatment of dairy wastewater. Water. Sci. Technol., 28, 67-76. 
Sarapatka, B. (1994). Factors influencing biogas production during full-scale anaerobic fermentation of farmyard manure. Biores. Technol., 49, 17-23. http://dx.doi.org/10.1016/0960-8524(94)90168-6

Sarkar, B., Chakrabarti, P. P., Vijaykumar, A., \& Kale, V. (2006). Wastewater treatment in dairy industries-possibility of reuse. Desalin., 195, 141-152. http://dx.doi.org/10.1016/j.desal.2005.11.015

Smithers, G. W. (2008). Whey and whey proteins-From 'gutter-to-gold'. Int. Dairy J, 18, 695-704. http://dx.doi.org/10.1016/j.idairyj.2008.03.008

Spece, R. E. (1999). Anaerobic biotechnology for industrial wastewater treatment. Water Sci. Tech., 23, 1259-1264. http://dx.doi.org/10.1021/es00115a001

Strik, D. P. B. T. B., Domnanovich, A. M., \& Holubar, P. (2006). A pH-based control of ammonia in biogas during anaerobic digestion of artificial pig manure and maize silage. Process Biochem., 41, 1235-1238. http://dx.doi.org/10.1016/j.procbio.2005.12.008

Tanik, A., Ates-Genceli, E., \& Ekdal, A. (2002). Chemical treatability of dairy wastewater. Environ. Manage. And Health 13, 163-174. http://dx.doi.org/10.1108/09566160210424590

Tarbaghia, T. M. (1993). Design of biogas plant to produce energy with special application to Benghazi, Libya. Renew. Energy, 3, 207-209.

Tchamango, S., Naseu-Njiki, C. P., Ngameni, E., Hadjiev, D., \& Darchen, A. (2010). Treatment od dairy effluents by electrocoagulation using aluminium electrodes. Sci of the Total Environ., 408, 947-952. http://dx.doi.org/10.1016/j.scitotenv.2009.10.026

Tritt, W. P. (1992). The anaerobic treatment of slaughterhouse wastewater in fixed-bed reactors. Bioresour. Tech., 41, 201-207. http:// dx.doi.org/10.1016/0960-8524(92)90002-F

Tritt, W. P., \& Schuchardt, F. (1992). Materials flow and possibilities of treating liquid and solid wastes from slaughterhouse in Germany. Biores. Tech., 41, 235-245. http://dx.doi.org/10.1016/0960-8524(92)90008-L

Umetsu, K., Yamazaki, S., Kishimoto, T., Takahashi, J., Shibata, Y., Zhang, C., ..., Komiyama, M. (2006). Anaerobic co-digestion of dairy manure and sugar beets. Int. Congress Series, 1293, 307-310. http://dx.doi.org/10.1016/j.ics.2006.03.025

Yan, J. Q., Lo, K. V., \& Liao, P. H. (1990). Anaerobic digestion of cheese whey using an upflow anaerobic sludge blanket reactor, III: sludge and substrate profiles. Biomass, 21, 257-271. http://dx.doi.org/10.1016/0144-4565(90)90076-V 